\begin{tabular}{c} 
Volume and Issues Obtainable at Center for Sustainability Research and Consultancy \\
Journal of Accounting and Finance in Emerging Economies \\
ISSN: 2519-0318 ISSN (E) 2518-8488 \\
Volume 3: Issue 2 December 2017 \\
JSRᄃ \\
Journal homepage: www.publishing.globalcsrc.org/jafee \\
\hline
\end{tabular}

\title{
Malaysian Acquiring Firms' Shareholders' Wealth Effect Following Cross-Border Acquisition
}

\author{
${ }^{1}$ Md. Mahadi Hasan, ${ }^{2}$ Yusnidah Ibrahim, ${ }^{3}$ Raji Jimoh Olajide, ${ }^{4}$ Mohd Sobri Minai, ${ }^{5}$ Md. Mohan Uddin \\ ${ }^{1} \mathrm{PhD}$ candidate, Department of Finance, School of Economics, Finance and Banking, Universiti Utara \\ Malaysia,Malaysia. \\ ${ }^{2}$ Professor, Dean and AVC, School of Economics, Finance and Banking, Universiti Utara Malaysia, Malaysia. \\ ${ }^{3}$ Senior Lecturer, School of Economics, Finance and Banking, Universiti Utara Malaysia, Malaysia. \\ ${ }^{4}$ Professor, School of Business Management, Universiti Utara Malaysia, Malaysia. \\ ${ }^{5}$ Associate Professor, School of Business and Economics, United International University, Bangladesh.
}

\section{ARTICLEDETAILS}

\section{History}

Revised format: Nov 2017

Available online: Dec 2017

\section{Keywords \\ Shareholders' Wealth Effect \\ (SWE), \\ Buy-and-Holder Abnormal \\ Return (BHAR), \\ Cross-Border Acquisitions \\ $(C B A)$, \\ Bursa Malaysia (BM)}

JEL Classification:

D31, G34

\begin{abstract}
Purpose: The purpose of this study is to investigate long run shareholders' wealth effect (SWE) of Malaysian acquiring firms following cross-border acquisition (CBA).

Methodology: Using buy-and-hold abnormal returns (BHAR) measure of SWE and Euclidean distance method for identifying matching firms, the study investigated $176 \mathrm{CBA}$ deals of Malaysian acquiring firms for the years 2004-2015. Both parametric tests (such as conventional t-statistics, skewness adjusted t-statistics, bootstrapping skewness adjusted t-statistics and Multivariate of Analysis of Variance) and non-parametric statistical (such as Wilcoxon-Mann-Whitney test) tools were employed to analyze the data and test the hypotheses regarding the impact of CBA deals on acquiring firms' SWE.
\end{abstract}

Results: The research found that the SWE of acquiring firms is significantly positive in the shorter period while negative or mixed in the longer period. Furthermore, SWE is found to be different across several groups: (i) Shariah-complaint status firms vs. conventional firms (ii) level of control in target firm (such as major vs. minor acquisitions), (iii) Diversifying acquisition (for example, related vs unrelated acquisition). However, SWE does not differ from industry to industry.

Implications:This research presents unique empirical evidences related to long run SWE of Malaysian acquiring firms following CBA. The findings imply that CBA is more success in the longer period.

(C) 2017 The authors, under a Creative Commons AttributionNonCommercial 4.0

Corresponding author's email address: mahadihasan82@gmail.com

Recommended citation:Hasan,M.M., Ibrahim,Y., Olajide,R.J., Minai.M.S \& Mohan Uddin,M., (2017). Malaysian Acquiring Firms' Shareholders' Wealth Effect Following Cross-Border Acquisition. Journal of Accounting and Finance in Emerging Economies, 3(2) 147-158. DOI:https://doi.org/10.26710/jafee.v3i2.95

\section{Introduction}

Acquiring firms face challenges posed by the new pattern of globalization, which has led to greater integration of their operations and control. Subsequently, corporate sector all over the world is 
restructuring its operations through different types of consolidation strategies. Cross-border acquisitions (CBA) is one of the most popular forms of such strategy. The CBA activities are expanding due to the deregulation of different government approaches as a facilitator of the neo-liberal economic regime among firms. The role of such CBA is also encouraging for longer-term reforms, such as operational restructuring, reallocation of assets, and wealth increase in firms (Mody \& Negishi, 2001).

In consonance with this, outbound foreign direct investment, in the form of CBA, has a significant role to play in the restructuring and continued development of the Malaysian economy (Rahim, Ahmad, \& Ahmad, 2016). It allows capital to be reallocated more freely to its highest use in economic terms. Reducing barriers for companies to transform and adjust to changing markets can be expected to result in capital being allocated more efficiently from an economic perspective. As a result, the volume of outbound CBA has been an increasing trend among Malaysian firms since 1990 (UNCTAD, 2014).

Nonetheless, despite the popularity of growth strategies based on CBA, where it was reported that globally companies spent more than $\$ 2$ trillion on all types of acquisitions every year (Bunce, 2013), the failure rates reported by several sources are high which are in the range of $70 \%$ to $90 \%$ (Rahim, Ahmad, Ahmad, \& Rahim, 2013; Bunce, 2013; Christensen, Alton, Rising \& Waldeck, 2011). More specifically for Malaysian market, PwC's surveys show that $70 \%$ of the M\&As fail in general (The Edge Malaysia, July 9, 2012).

It is rather puzzling that given the high reported failure rate of CBA, the strategy is still widely pursued. Could it be that the performance measure used is not accurate enough to reflect the real value of CBA and/or that CBA indeed delivers higher value in firms with specific characteristics. As the essence of CBA for acquiring firms lies in achieving the long run goal of shareholders' wealth maximization, it is crucial to assess the performance of CBA based on whether this restructuring generates value gains for shareholders of the acquirers, how these value gains have been created and achieved or failed.

The novel contribution of this study is in terms of unveiling the performance of Malaysian CBA using a robust performance measure of wealth effects, which is the Buy and Hold Abnormal Returns for one, two and three years following CBA activities and comparing the performance across different category of firms. 4 categorizations of firm were investigated, namely (1) Shariah-complaint status firms vs. conventional firms, (2) level of control in target firm (including Major vs. Minor acquisitions), (3) diversifying acquisitions, and (4) industry effect of acquiring firms. Shariah-complaint firm has an extra Shariah supervisory board compare to conventional firm. This Supervisory board is an independent body of monitoring the firm which can improve its performance. Major control in target firm can reduce agency cost which leads to maximize shareholder wealth. Diversified acquisition can also reduce risk. Therefore, these groups of firm expect to do better than conventional firms in CBA.

The success and failure of these transactions are of great significance and have enormous consequences for the companies themselves as well as for the other groups in them (Sudarsanam, 2010). Thus, examination of the SWEfollowing CBA demands extensive research.

\section{Literature Review}

Prior literatures reported that studies on SWE exhibit puzzling resultsdue to different type of samples, methods, time periods, and difference of the market contexts. Therefore, there is a need for further study on SWE.However, only a few studies were conducted on Malaysian acquiring firms' SWE and these were mostly conducted on short run SWE (Rahim et al., 2016; Rahim et al., 2013, 2014). On the other hand, to the best of author's knowledge, only the study by Khin, Lee, and Yee (2012) was conducted on long run SWE. There are a few studies on SWE of firms following domestic merger and acquisition (M\&A) as 
well, for example, Peng and Isa (2012), Aik, Hassan, and Mohamad (2015), Shahar, Mohd, and Ishak (2016) and Mat Rahim and Ching Pok (2013).

The only Malaysian long run SWE study of CBA by Khin et al. (2012) reported positive SWE using cumulative abnormal returns (CAR) considering different event windows including 60, 120 and 180 days during the period of 2004-2007. Nevertheless, the measurement of the long run SWE using CAR has some limitations for long event window. The limitations are mainly the bias, which includes new listing bias and rebalancing bias (Barber \& Lyon, 1997; Basuil \& Datta, 2015; Oler, Harrison, \& Allen, 2008). Furthermore, their study is incomparable with most of the previous studies that used event windows of 12, 24, and 36 months after acquisition for long run SWE (Banerjee, Banerjee, De, Jindra, \& Mukhopadhyay, 2014; Wang, Shih, \& Lin, 2014). The period of the study was 2004-2007, which was relatively short. Consequently, the study of long run SWE of CBAs is still nascent in the Malaysian context. Therefore, it clearly shows the need for undertaking further examination of the profile of SWE of the acquiring firm following CBA in the long run from the Malaysian context.

To the best of authors' knowledge, there is hardly any evidence found considering the following aspects in the long run SWE following CBA in Malaysian context in the previous studies: (1) long run SWE of acquiring firm of post 12, 24 and 36 months, (2) percentage of firms (either gainer firms or loser firms), (3) SWE of Shariah-complaint status firms vs. conventional firms, (4) level of control in target firm (including Major vs. Minor acquisitions), (5) diversifying acquisitions, and (6) industry effect of acquiring firms.

\section{Methodology}

Long-horizon event study used in this research has a long history of development including the original one by Fama, Fisher, Jensen, and Roll (1969). However, in order to get the best result, the state-of-the-art method based on recent and key studies on long run event study (Barber \& Lyon, 1997; Fama, 1998; Jegadeesh \& Karceski, 2009; Kothari \& Warner, 1997, 2004; Lyon, Barber, \& Tsai, 1999; Mitchell \& Stafford, 2000; Viswanathan \& Wei, 2008) is followed.

The results of long run event studies are sensitive to both the methodology used and the benchmark employed (Agrawal, Jaffe, \& Mandelker, 1992; Ibrahim, Uddin, Mohd, \& Minai, 2013; Pontiff \& Woodgate, 2008; Rau \& Vermaelen, 1998). This is why, using appropriate method to calculate abnormal returns and comparing them to an appropriate benchmark are the two most important aspects of determining long run wealth effect. BHAR approach of post-event performance is used in this study employing characteristics-based benchmark using Euclidean distance method (Berry, Guillén, \& Zhou, 2010; Swaminathan, Murshed, \& Hulland, 2008; Van Heerde, Gijsbrechts, \& Pauwels, 2008). The benchmark characteristics are firm size and firm growth. Firm size and firm growth are measured by market capitalization and book to market value respectively. Following are the steps of calculating BHAR.

Calculation of Monthly (t) Raw Return $\left(r_{i t}\right)$ for each firm $(i)$ from Return Index.

$$
r_{i t}=\frac{R_{i t}-R_{i(t-1)}}{R_{i(t-1)}}
$$

Calculating BHAR is to calculate the holding period return of firm $i$ for the analysis period in months $(T)$,

$$
B H R_{i, T}=\prod_{t=1}^{T}\left(1+r_{i t}\right)-1
$$

Where, $r_{i t}$ is the monthly raw return of firm $i$ in month $t$. Using the same calculation, the holding period return for the benchmark $b$ is, 


$$
B H R_{b, T}=\prod_{t=1}^{T}\left(1+r_{b t}\right)-1
$$

Now, the buy-and-hold abnormal return for each firm $i$ in month $t$ after benchmark adjustment is the difference between the buy-and-hold returns of the firm and the benchmark,

$$
B H A R_{i t}=B H R_{i t}-B H R_{b t}
$$

which is used for calculating the value weighted $\left(w_{i}\right)$ mean of the buy-and-hold abnormal return (BHAR) for month $t$ as follows,

$$
\overline{B_{H A R_{t}}}=\sum_{i=1}^{n_{t}} w_{i} B H A R_{i t}
$$

The test of statistical significance is conducted using three procedures for the purpose of robustness and comparability with other studies. These are: (1) conventional $t$-statistic, (2) skewness adjusted $t$-statistic, and (3) bootstrapped skewness adjusted $t$-statistic, suggested by Lyon et al. (1999) and developed by Johnson (1978).

Moreover, using parametric tests (such as conventional t-statistics, skewness adjusted t-statistics, bootstrapping skewness adjusted t-statistics and Multivariate Analysis of Variance) and non-parametric statistical (such as Wilcoxon-Mann-Whitney test) tools were used to analyze the data and test the hypotheses regarding acquiring firms' SWE impacted by CBA deals.

Malaysian acquiring firms' CBA deals were identified from Thomson Reuters Eikon database. After that, on the basis of these deals, firm's related data were collected from DataStream database. Thereafter, total sample were 332, 284 and 176 for 12, 24 and 36 months of long run SWEs, respectively. Considering 36 months as a long run post acquisition period, final sample is 176 for 12, 24 and 36 months which make uniform across time (such as 12, 24 and 36 months). Stock return, firm size, market to book value related data are also collated form DataStream database. Shariah-compliant status firms were identified from Bursa Malaysia website. Industry classification is defined from DataStream database using Industry four group. Level of acquisition in target firm, and diversifying or unrelated industry deals were identified from Thomson Reuters Eikon database.

\section{Findings and Discussion \\ 4.1 Descriptive Analysis}

Descriptive statistics of the variables are reported in Table 4.1 and 4.2. However, only the firms with available data for all variables were included in the analysis as can be seen in Table 4.1 and 4.2. The research employs cross-sectional data analysis of $176 \mathrm{CBA}$ deals-firms observations for the period of 2004-2015 considering 12 months, 24 months and 36 months post acquisition wealth effect of acquiring firms.

Panel A: Equally weighted BHAR explains outcome variable (shareholder's wealth effect of acquiring firms) following 12 month, 24 months and 36 months respectively. Panel B: Value weighted BHAR is for the same. Panel C: Comparison between groups within sample for firms and across time period (such 12 months, 24 months and 36 months). 
Table 4.1: Outcome variables

\begin{tabular}{lccccc}
\hline Variable & $\begin{array}{c}\text { No of } \\
\text { CBA deals }\end{array}$ & Mean & Std. Dev. & Min & Max \\
\hline \multicolumn{7}{c}{ Panel A: Equally weighted BHAR } \\
\hline BHAR12EW & 176 & 0.0085014 & 0.7151507 & -1.718748 & 5.523083 \\
\hline BHAR24EW & 176 & -0.028017 & 1.04188 & -2.28526 & 8.157512 \\
\hline BHAR36EW & 176 & -0.1150517 & 1.266338 & -5.528052 & 7.925235 \\
\hline BHAR12VW & 176 & 0.000038 & 0.0023817 & -0.0174151 & 0.0189255 \\
\hline BHAR24VW & 176 & 0.0000184 & 0.0024892 & -0.019994 & 0.0152472 \\
\hline BHAR36VW & 176 & 0.0002857 & 0.0042072 & -0.0256878 & 0.0270278 \\
\hline
\end{tabular}

Note: BHAR12EW=Equally weighted Buy-and-hold abnormal returns of post-12 months, BHAR24EW= Equally weighted Buy-and-hold abnormal returns of post-24 months, BHAR36EW= Equally weighted Buy-and-hold abnormal returns of post-36 months, BHAR12VW= Value weighted Buy-and-hold abnormal returns of post-12 months, , BHAR24VW=Value weighted Buy-and-hold abnormal returns of post-24 months, BHAR36VW=Value weighted Buy-and-hold abnormal returns of post-36 months.

(i): Panel C: Group-wise sample

(i) Shariah-complaint status of acquiring firms (SCS)

Seventy-three percent (73\%) deal of acquiring firm has Shariah-complaint status which is 128 out 176 . So most of deals' acquiring has shariah-complaint status in the Bursa Malaysia following CBA.

Table 4.2 (i): Shariah-complaint status firms

\begin{tabular}{cccc}
\hline Firm Shariah status & Freq. & Percent & Cum. \\
\hline Conventional firms & 48 & 27 & 27.27 \\
\hline Shariah-complain status firms & 128 & 73 & 100 \\
\hline Total & 176 & 100 & \\
\hline
\end{tabular}

(ii) Level of acquisition (LA) in target firms

Eighty-five percent (85\%) of CBA deals which control in target firms - is greater than or equal to $33 \%$. It means Malaysian acquiring firms like to acquire major control in target firm.

\section{Table 4.2 (ii): Level of acquisition}

\begin{tabular}{cccc}
\hline Level of acquisitions & Freq. & Percent & Cum. \\
\hline Minor acquisition & 27 & 15 & 15.34 \\
\hline Major acquisition & 149 & 85 & 100 \\
\hline Total & 176 & 100 & \\
\hline
\end{tabular}

Note: if a CBA deal of acquiring firm acquires the target firm more than or equal to 33\%, the deal is considered as major acquisition, otherwise it is minor acquisition in target firms.

(iii) Diversifying acquisition strategy (DAS)

$83 \%$ of CBA deals of acquiring firms acquire the target which is not related industry with acquiring industry. It shows that acquiring firm like to buy unrelated industry of target firms.

\section{Table 4.2 (iii): Diversifying acquisition}

\begin{tabular}{cccc}
\hline Diversifying acquisition & Freq. & Percent & Cum. \\
\hline Related industry acquisition & 30 & 17 & 17.05 \\
\hline Unrelated industry acquisition & 146 & 83 & 100 \\
\hline Total & 176 & 100 & \\
\hline
\end{tabular}

Note: if a CBA deal of acquiring firm acquires an unrelated industry's target, it is considered as diversifying acquisitions strategy, otherwise it is related industry acquisitions. 
(iv) Acquiring firm's industry

Eighty-nine percent (89\%) of CBA deals of acquiring industry is industrial which is 157 out of 176 . Most of firm go for CBA deal which are from industrial industry.

\section{Table 4.2 (iv): Industry of acquiring firms}

\begin{tabular}{cccc}
\hline Industry of acquiring firms & Freq. & Percent & Cum. \\
\hline Non-industrial industry & 19 & 11 & 10.8 \\
\hline Industrial Industry & 157 & 89 & 100 \\
\hline Total & 176 & 100 & \\
\hline
\end{tabular}

Note: if a CBA deal of acquiring firm is from industrial is Industrial industry it is considered from industrial industry acquisition, otherwise it is non-industrial industry acquisition.

\subsection{Findings}

\subsubsection{Gainer vs loser deals}

On an average, $40 \%$ deals of acquiring firms have increased their shareholders wealth while $60 \%$ of deal of acquiring firms have decreased their shareholders' wealth after 36 months of acquisition as shown in Table 4.3 (i). So it is evident that $60 \%$ CBA deals of acquiring failed to create SWE. It can be said that failure rate exceeds success rate. The finding is similar to the previous studies by Rahim et al. (2013) and Aybar and Ficici (2009).

Table 4.3 (i): Gainer and loser deal status

\begin{tabular}{lccc}
\hline Gain and loser deals & BHAR12 & BHAR24 & BHAR36 \\
\hline Loser $(\%)$ & 59 & 59 & 60 \\
\hline Gainer $(\%)$ & 41 & 41 & 40 \\
\hline
\end{tabular}

\subsubsection{Acquiring firm shareholders' wealth effect}

Using equally weighted buy-and-hold abnormal returns (BHAR-EW), SWE was found significantly positive in 12 months while after 12 months, it was found significantly negative and gradually negative. So it is evident that SWE is positive in shorter period but negative in the longer period as shown in Table 4.3 (ii). On the other hand, Using value weighted buy-and-hold abnormal returns (BHAR-VW), SWE was found significantly positive following 12 months, 24 months and 36 months. It is evident that SWE is positive in the long run due to the change of method of measurement as shown in Table 4.3 (iii). Moreover, as shown in Figure 4.1 the SWE is found to show be showing an upward trend using BHARVW model while SWE is to be showing a downward trend using BHAR-EW model for 1-36 months. So the results of SWE is showing a mixed effect due to methods to measure it.

The results of SWE is found similar to previous studies. For example, the results of SWE is mixed due to use of different methods of measurements (such as Basuil \& Datta, 2015; Khin et al., 2012). In line with this, several previous studies found that SWE is positive in the shorter period such as day or month to year (Bhagat et al., 2011; Khin et al., 2012) while others (Bertrand \& Betschinger, 2012; Wang et al., 2014) found a negative one in the longer period ( such as 12 months to 36 months post acquisition). Moreover, some studies report positive SWE of acquiring firms in long run (Banerjee et al., 2014; Francis et al., 2014).

Table 4.3 (ii): BHAR-EW

\begin{tabular}{lccccc}
\hline Post Period & Sample Size & BHAR-EW $(\%)$ & \multicolumn{2}{c}{$t$-statistics } \\
\cline { 4 - 6 } & & & $t_{c}{ }^{a}$ & $t_{s a}{ }^{b}$ & $t_{b s a}{ }^{c}$ \\
\hline 1 to 12 Months & 176 & 0.8501 & $15.77^{* * *}$ & $7.06^{* * *}$ & $9.37 * * *$ \\
\hline 1 to 24 Months & 176 & -2.802 & $-35.67 * * *$ & $8.67 * * *$ & $8.67 * * *$ \\
\hline 1 to 36 Months & 176 & -11.50 & $-120.53^{* * *}$ & $13.03^{* * *}$ & $9.70^{* * *}$ \\
\hline
\end{tabular}


Note: BHAR-EW= Equally weighted Buy-and-hold abnormal returns

$*$, **, and *** indicate $10 \%, 5 \%$, and $1 \%$ level of significance, respectively.

$t_{c}{ }^{a}=$ conventional $t$-statistics.

$t_{s a}{ }^{b}=$ Skewness adjusted $t$-statistics.

$t_{b s a}{ }^{c}=$ bootstrapped skewness adjusted t-statistics.

Table 4.3 (iii): BHAR-VW

\begin{tabular}{cccccc}
\hline Post Period & Sample Size & BHAR-VW & \multicolumn{3}{c}{ t-statistics } \\
\cline { 3 - 6 } & & $(\%)$ & $\mathrm{t}_{\mathrm{c}}{ }^{\mathrm{a}}$ & $\mathrm{t}_{\mathrm{sa}}{ }^{\mathrm{b}}$ & $\mathrm{T}_{\mathrm{bsa}}{ }^{\mathrm{c}}$ \\
\hline 1 to 12 Months & 176 & 0.0038 & $21.17^{* * *}$ & $2.45^{* * *}$ & $6.58^{* * *}$ \\
\hline 1 to 24 Months & 176 & 0.0018 & $9.79 * * *$ & $-5.53 * * *$ & $-27.43^{* * *}$ \\
\hline 1 to 36 Months & 176 & 0.0286 & $90.08 * * *$ & $-2.09 * * *$ & $5.48^{* * *}$ \\
\hline
\end{tabular}

Note: $B H A R-V W=$ Value weighted Buy-and-hold abnormal returns

$*$, **, and *** indicate $10 \%, 5 \%$, and $1 \%$ level of significance, respectively.

$t_{c}^{a}=$ conventional $t$-statistics .

$t_{\text {sa }}{ }^{b}=$ Skewness adjusted $t$-statistics.

$t_{b s a}{ }^{c}=$ bootstrapped skewness adjusted $t$-statistics.

Graph of BHAR-EW and BHAR-VW

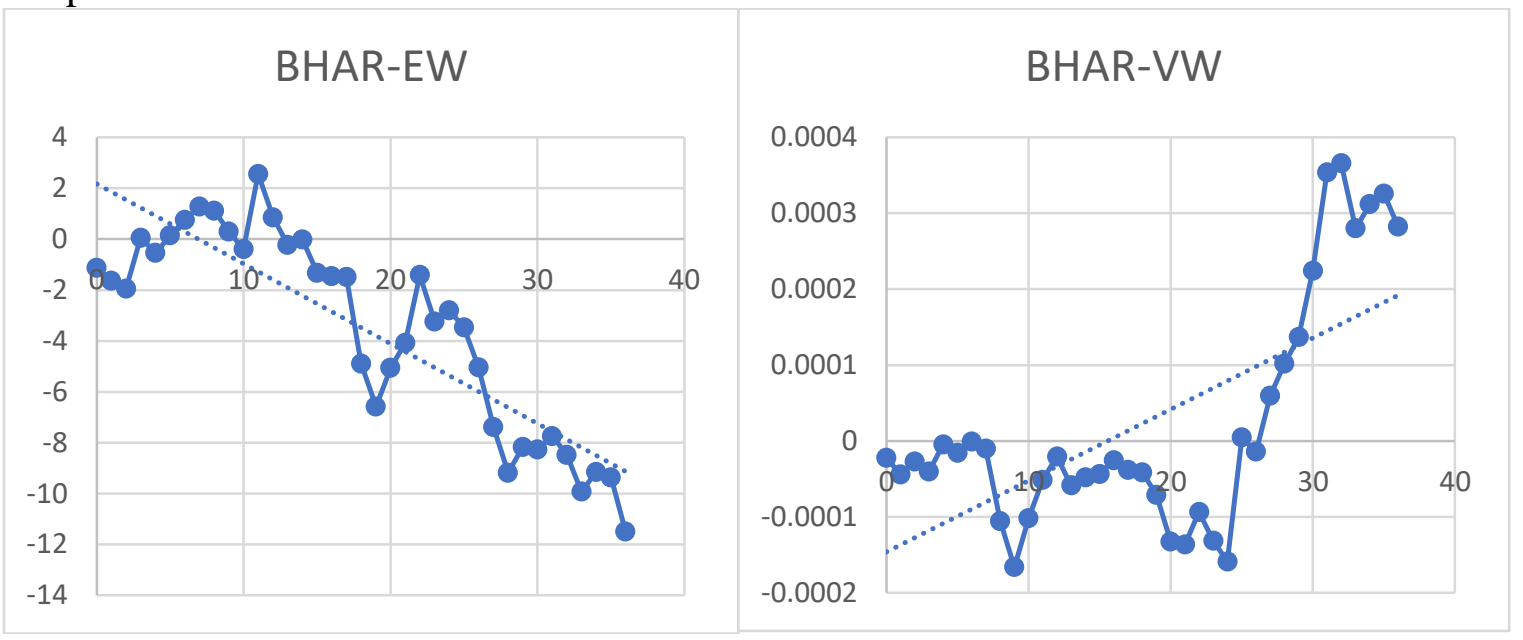

Figure 4.1: Monthly BHAR (equally weighted and value weighted)

\subsubsection{Comparison within groups and over time of SWE}

Independent group $t$-test (for parametric and non-parametric test) is designed to compare means of same variable between two groups. Ideally, these subjects are randomly selected from a larger population of subjects. The test assumes that variances for the two populations are the same. The interpretation for $\mathrm{p}$ value is the two-tailed $p$-value computed using the $t$ distribution. It is the probability of observing a greater absolute value of $\mathrm{t}$ under the null hypothesis. If the $p$-value is less than the pre-specified alpha level (usually 0.05 or 0.01 , here the former) it can be concluded that mean difference between group 1 and group2 is statistically significantly different from zero. In the same way for Multivariate Analysis of Variance (MANOVA), the $p$-value associated with the $F$ statistic of a given effect and test statistic. The null hypothesis that a given predictor has no effect on either of the outcomes is evaluated with regard to this $p$-value. For a given alpha level (usually 0.05 or 0.01 , here the former), if the $p$-value is less than alpha, the null hypothesis is rejected. If not, then we fail to reject the null hypothesis.

However, the results of SWE indicate that there is no statistically significant difference between the mean SWE for Shariah vs. Conventional firms, Major vs. Minor, and Diversifying vs. similar acquisition as shown by independent group t-test (parametric test) in Table 4.4 (i) and Table 4.4 (ii). Moreover, using 
non-parametric test such as Wilcoxon-Mann-Whitney test, the results this study found are the same for each group of samples. But, acquiring firm SWE differs across industry when SWE is measured by BHAR-VW. Furthermore, the results of MANOVA also indicate that SWE differs from industry to industry.

\section{Table 4.4 (i): BHAR-EW}

\begin{tabular}{|c|c|c|c|c|c|c|c|c|c|c|}
\hline \multirow[t]{2}{*}{ Factors } & \multirow[t]{2}{*}{$\begin{array}{l}\text { Difference } \\
\text { mean }\end{array}$} & \multicolumn{2}{|c|}{ Group } & \multirow[t]{2}{*}{$\begin{array}{c}\text { Total } \\
\text { observations }\end{array}$} & \multicolumn{2}{|c|}{$\begin{array}{c}\text { Independent group } \boldsymbol{t} \text { - } \\
\text { test }\end{array}$} & \multicolumn{2}{|c|}{$\begin{array}{l}\text { Wilcoxon-Mann- } \\
\text { Whitney test }\end{array}$} & \multicolumn{2}{|c|}{ MANOVA } \\
\hline & & 1 & 0 & & $t$-value & $p$-value & $z$-value & p-value & $\begin{array}{c}f- \\
\text { value }\end{array}$ & $\begin{array}{c}p- \\
\text { value }\end{array}$ \\
\hline \multirow[t]{3}{*}{ SCS } & BHAR12EW & 128 & 48 & 176 & -0.3588 & 0.7202 & -0.169 & 0.8655 & 0.96 & 0.41 \\
\hline & BHAR24EW & 128 & 48 & 176 & 0.0491 & 0.9609 & 0.462 & 0.6443 & & \\
\hline & BHAR36EW & 128 & 48 & 176 & -0.8544 & 0.3940 & -0.688 & 0.4917 & & \\
\hline \multirow[t]{3}{*}{ LA } & BHAR12EW & 149 & 27 & 176 & -0.6601 & 0.5101 & -1.102 & 0.2704 & 0.44 & 0.72 \\
\hline & BHAR24EW & 149 & 27 & 176 & -0.0732 & 0.9417 & -0.454 & 0.6501 & & \\
\hline & BHAR36EW & 149 & 27 & 176 & -0.3792 & 0.7050 & -0.946 & 0.3440 & & \\
\hline \multirow[t]{3}{*}{ DAS } & BHAR12EW & 146 & 30 & 176 & -0.2364 & 0.8134 & 0.956 & 0.3391 & 1.09 & 0.35 \\
\hline & BHAR24EW & 146 & 30 & 176 & -1.2954 & 0.1969 & -0.602 & 0.5472 & & \\
\hline & BHAR36EW & 146 & 30 & 176 & -1.1137 & 0.2669 & -1.141 & 0.2539 & & \\
\hline \multirow[t]{3}{*}{ AI } & BHAR12EW & 157 & 19 & 176 & 1.4101 & 0.1603 & 1.375 & 0.1690 & 1.1 & 0.34 \\
\hline & BHAR24EW & 157 & 19 & 176 & 0.8157 & 0.4158 & 0.961 & 0.3367 & & \\
\hline & BHAR36EW & 157 & 19 & 176 & 1.2377 & 0.2175 & 0.694 & 0.4879 & & \\
\hline
\end{tabular}

Note:1= Shariah complaint-status (SCS) or Major acquisition (LA) or Related industry of acquisition (RI) or material industry of acquirer (Industry) or region in Asia (Region), Otherwise $=0$.

$*, * *$, and $* * *$ indicate $10 \%, 5 \%$, and $1 \%$ level of significance, respectively.

Table 4.4 (ii):BHAR-WV

\begin{tabular}{|c|c|c|c|c|c|c|c|c|c|c|}
\hline \multirow[t]{2}{*}{ Factors } & \multirow[t]{2}{*}{$\begin{array}{l}\text { Difference } \\
\text { mean }\end{array}$} & \multicolumn{2}{|c|}{ Group } & \multirow[t]{2}{*}{$\begin{array}{c}\text { Total } \\
\text { observations }\end{array}$} & \multicolumn{2}{|c|}{$\begin{array}{c}\text { Independent group t- } \\
\text { test }\end{array}$} & \multicolumn{2}{|c|}{$\begin{array}{l}\text { Wilcoxon-Mann- } \\
\text { Whitney test }\end{array}$} & \multicolumn{2}{|c|}{ MANOVA } \\
\hline & & 1 & 0 & & $t$-value & $p$-value & $z$-value & $\begin{array}{c}p- \\
\text { value }\end{array}$ & $\begin{array}{c}f- \\
\text { value }\end{array}$ & $p$-value \\
\hline \multirow[t]{3}{*}{ SCS } & BHAR12WV & 128 & 48 & 176 & -0.4824 & 0.6301 & 0.249 & 0.8033 & 1.29 & 0.28 \\
\hline & BHAR24WV & 128 & 48 & 176 & 0.263 & 0.7929 & 1.581 & 1.581 & & \\
\hline & BHAR36WV & 128 & 48 & 176 & 0.9978 & 0.3197 & 0.515 & 0.6066 & & \\
\hline \multirow[t]{3}{*}{ LA } & BHAR12WV & 149 & 27 & 176 & 0.262 & 0.7936 & -1.176 & 0.2395 & 2.03 & 0.11 \\
\hline & BHAR24WV & 149 & 27 & 176 & -1.7119 & $0.0887^{*}$ & -1.250 & 0.2113 & & \\
\hline & BHAR36WV & 149 & 27 & 176 & -0.5026 & 0.6159 & -1.234 & 0.2174 & & \\
\hline \multirow[t]{3}{*}{ DAS } & BHAR12WV & 146 & 30 & 176 & -0.1686 & 0.8663 & 0.531 & 0.5953 & 0.16 & 0.93 \\
\hline & BHAR24WV & 146 & 30 & 176 & -0.2891 & 0.7728 & -0.508 & 0.6118 & & \\
\hline & BHAR36WV & 146 & 30 & 176 & -0.5788 & 0.5635 & -1.326 & 0.1849 & & \\
\hline \multirow[t]{3}{*}{ AI } & BHAR12WV & 157 & 19 & 176 & -2.9451 & $0.0037 * * *$ & -0.155 & 0.8769 & 5.43 & $0.00 * * *$ \\
\hline & BHAR24WV & 157 & 19 & 176 & -3.5896 & $0.0004 * * *$ & -0.594 & 0.5528 & & \\
\hline & BHAR36WV & 157 & 19 & 176 & -3.9463 & $0.0001 * * *$ & -0.899 & 0.3688 & & \\
\hline
\end{tabular}

Note: I = shariah complain-status (SCS) or Major acquisition (LA)or Related industry of acquisition (RI) or material industry of acquirer (Industry) or region in Asia (Region), Otherwise $=0$.

$*, * *$, and $* * *$ indicate $10 \%, 5 \%$, and $1 \%$ level of significance, respectively.

\section{Concluding Remarks}

In this study, we made an attempt to empirically investigate long run SWE of Malaysian acquiring firms follow cross-border acquisitions. Our investigation reveals that most of the CBA deals of acquiring firm 
failed to create SWE in the long run. As empirically evidenced, only $40 \%$ CBA deals create SWE. As a whole, the results of Malaysian acquiring firms' SWE is mixed and could be attributed to the difference in the methods of measurement used. It is evident that SWE is positive in the short run. In the long run, SWE is positive if we use value weighted BHAR model while it is negative if we use equally weighted BHAR model. Furthermore, acquiring firm SWEs differ across industry. In contrast, there is no difference of SWE between Shariah complaint and conventional firms, major control firm and minor control firms, diversifying firm and related acquisition firms, etc. Finally, it is concluded that increasing long run SWE can be one of the goals of an acquiring firm. We recommend that the firms from industrial industry can go for CBA with the goal of increasing long run SWE. Also, it may consider CBA deals for buying raw material, expanding the market, and setting up new business in foreign markets.

\section{References}

Agrawal, A., Jaffe, J. F., \& Mandelker, G. N. (1992). The post-merger performance of acquiring firms: a re-examination of an anomaly. The Journal of Finance, 47(4), 1605-1621.

Aik, N. C., Hassan, T., \& Mohamad, S. (2015). Do Malaysian Horizontal Mergers and Acquisitions Create Value? Global Business Review, 16(5 suppl), 15S-27S.

Amin Noordin, B. A., Kamarudin, F., \& Mohamad Anwar, N. A. (2015). Wealth Effect and Macroeconomics Factors of a Firm's International Merger and Acquisition Exercise: Empirical Evidence from Multinational Firms. Engineering Economics, 26(5), 469-477.

Aw, M., \& Chatterjee, R. (2004). The performance of UK firms acquiring large cross-border and domestic takeover targets. Applied Financial Economics, 14(5), 337-349.

Aybar, B., \& Ficici, A. (2009). Cross-border acquisitions and firm value: An analysis of emerging-market multinationals. Journal of International Business Studies, 40(8), 1317-1338.

Banerjee, P., Banerjee, P., De, S., Jindra, J., \& Mukhopadhyay, J. (2014). Acquisition pricing in India during 1995-2011: Have Indian acquirers really beaten the odds? Journal of Banking \& Finance, 38, 14-30.

Barber, B. M., \& Lyon, J. D. (1997). Detecting long-run abnormal stock returns: The empirical power and specification of test statistics. Journal of Financial Economics, 43(3), 341-372.

Basuil, D. A., \& Datta, D. K. (2015). Effects of Industry-and Region-Specific Acquisition Experience on Value Creation in Cross-Border Acquisitions: The Moderating Role of Cultural Similarity. Journal of Management Studies, 52(6), 766-795.

Berry, H., Guillén, M. F., \& Zhou, N. (2010). An institutional approach to cross-national distance. Journal of International Business Studies, 41(9), 1460-1480.

Bertrand, O., \& Betschinger, M.-A. (2012). Performance of domestic and cross-border acquisitions: Empirical evidence from Russian acquirers. Journal of Comparative Economics, 40(3), 413-437.

Bhagat, S., Malhotra, S., \& Zhu, P. (2011). Emerging country cross-border acquisitions: Characteristics, acquirer returns and cross-sectional determinants. Emerging markets review, 12(3), 250-271.

Chari, A., Ouimet, P. P., \& Tesar, L. L. (2010). The value of control in emerging markets. Review of Financial Studies, 23, 1741-1770.

Conn, R. L., Cosh, A., Guest, P. M., \& Hughes, A. (2005). The impact on UK acquirers of domestic, cross-border, public and private acquisitions. Journal of Business Finance \& Accounting, 32(5-6), 815-870.

Dutta, S., \& Jog, V. (2009). The long-term performance of acquiring firms: A re-examination of an anomaly. Journal of Banking \& Finance, 33(8), 1400-1412.

Fama, E. F. (1998). Market efficiency, long-term returns, and behavioral finance. Journal of Financial Economics, 49(3), 283-306.

Fama, E. F., Fisher, L., Jensen, M. C., \& Roll, R. (1969). The adjustment of stock prices to new information. International economic review, 10(1), 1-21.

Francis, B. B., Hasan, I., Sun, X., \& Waisman, M. (2014). Can firms learn by observing? Evidence from cross-border M\&As. Journal of Corporate Finance, 25, 202-215. 
Ibrahim, Y., Uddin, M. M., Mohd, K. N. T., \& Minai, M. S. (2013). Agency Costs and the Long-Run Performance of Debt Issuers. Asian Academy of Management Journal of Accounting and Finance, 9(1), 67-87.

Jegadeesh, N., \& Karceski, J. (2009). Long-run performance evaluation: Correlation and heteroskedasticity-consistent tests. Journal of Empirical Finance, 16(1), 101-111.

Johnson, N. J. (1978). Modified t tests and confidence intervals for asymmetrical populations. Journal of the American Statistical Association, 73(363), 536-544.

Khin, E. W. S., Lee, L. Y., \& Yee, C. M. (2012). Cross-border mergers and acquisitions: Malaysian perspective. Actual Problems of Economics, 134(8).

Kothari, S., \& Warner, J. B. (1997). Measuring long-horizon security price performance. Journal of Financial Economics, 43(3), 301-339.

Kothari, S., \& Warner, J. B. (2004). The econometrics of event studies. Available at SSRN 608601.

Lyon, J. D., Barber, B. M., \& Tsai, C. L. (1999). Improved methods for tests of long-run abnormal stock returns. The Journal of Finance, 54(1), 165-201.

Martynova, M., \& Renneboog, L. (2011). The performance of the European market for corporate control: Evidence from the fifth takeover wave. European financial management, 17(2), 208-259.

Mat Rahim, N., \& Ching Pok, W. (2013). Shareholder wealth effects of M\&As: the third wave from Malaysia. International Journal of Managerial Finance, 9(1), 49-69.

Mitchell, M. L., \& Stafford, E. (2000). Managerial decisions and long-term stock price performance. The Journal of Business, 73(3), 287-329.

Mody, A., \& Negishi, S. (2001). Cross-border mergers and acquisitions in East Asia: trends and implications. Finance and Development, 38(1), 6-9.

Moeller, S. B., \& Schlingemann, F. P. (2005). Global diversification and bidder gains: A comparison between cross-border and domestic acquisitions. Journal of Banking \& Finance, 29(3), 533-564.

Moeller, S. B., Schlingemann, F. P., \& Stulz, R. M. (2004). Firm size and the gains from acquisitions. Journal of Financial Economics, 73(2), 201-228.

Oler, D. K., Harrison, J. S., \& Allen, M. R. (2008). The danger of misinterpreting short-window event study findings in strategic management research: an empirical illustration using horizontal acquisitions. Strategic Organization, 6(2), 151-184.

Peng, L. S., \& Isa, M. (2012). Long-term share performance of Malaysian acquiring firms. Managerial Finance, 38(10), 958-976.

Pontiff, J., \& Woodgate, A. (2008). Share Issuance and Cross-sectional Returns. The Journal of Finance, 63(2), 921-945.

Rahim, K. F., Ahmad, N., \& Ahmad, I. (2016). Assessing of Malaysian Firms' Cross-Border Merger and Acquisition Efficiency. Paper presented at the Proceedings of the 1st AAGBS International Conference on Business Management 2014 (AiCoBM 2014).

Rahim, K. F., Ahmad, N., Ahmad, I., \& Rahim, F. A. (2013). Determinants of Cross Border Merger and Acquisition in Advanced Emerging Market Acquiring Firms. Procedia Economics and Finance, 7 , 96-102.

Rahim, K. F., Ahmad, N., Ahmad, I., \& Rahim, F. A. (2014). Malaysia and Taiwan Acquiring Firms' Short-run Performance in Cross Border Mergers and Acquisitions. European Financial Systems, 55(3), 499.

Rau, P. R., \& Vermaelen, T. (1998). Glamour, value and the post-acquisition performance of acquiring firms. Journal of Financial Economics, 49(2), 223-253.

Shahar, H. K., Mohd, K. N. T., \& Ishak, N. H. (2016). Long run stock performance of malaysian acquirers. International Journal, 1(2), 52-57.

Sudarsanam, S. (2010). Creating value from mergers and acquisitions: The challenges: An integrated and international perspective (2nd ed.). Harlow: Prentice Hall. 
Swaminathan, V., Murshed, F., \& Hulland, J. (2008). Value creation following merger and acquisition announcements: the role of strategic emphasis alignment. Journal of Marketing Research, 45(1), 33-47.

UNCTAD. (2014). United Nations Conference on Trade and Development (UNCTAD) 2014. World Investment Report 2014: cross-border mergers and acquisitions and development, United Nations, NY and Geneva.

Van Heerde, H. J., Gijsbrechts, E., \& Pauwels, K. (2008). Winners and losers in a major price war. Journal of Marketing Research, 45(5), 499-518.

Viswanathan, S., \& Wei, B. (2008). Endogenous events and long-run returns. Review of Financial Studies, 21(2), 855-888.

Wang, S.-F., Shih, Y.-C., \& Lin, P.-L. (2014). The Long-Run Performance of Asian Commercial Bank Mergers and Acquisition. Modern Economy, 5(4), 341. 
